\title{
How, when, and where information about breast cancer in Brazil is found using Google
}

\author{
Nicole Mayumi Hafner Ohira' ${ }^{1}$, Douglas Soltau Gomes²* (D)
}

\section{ABSTRACT}

Introduction: This article sought to clarify the sources that women seek to find information about breast cancer. Methods: With a data collection from Google Trends, it was possible to list which keywords are most used when the population performs these searches and to know the volume of searches for the words "breast cancer" (câncer de mama), "breast self-exam" (autoexame de mama), and "mammography" (mamografia) from 2009 to 2019. Results: In the search for "breast cancer" (câncer de mama), it was seen that the searches for "breast cancer" (câncer de mama), "breast cancer symptoms" (câncer de mama sintomas), "symptoms of breast cancer" (sintomas de câncer de mama), "what is cancer of breast" (o que é câncer de mama), and "types of breast cancer" (tipos de câncer de mama) are the five most prevalent. Data were also displayed that reflect the importance of the awareness campaign for this type of cancer, the Pink October, since the months of October of the years in question were the ones that had the highest search volume for the keywords "cancer of breast" (câncer de mama), "breast self-examination" (autoexame de mama), and "mammography" (mamografia). In addition, it was noticed that many sites with a greater chance of getting hits due to their being in the first places in the survey did not have the name of the sources from which they had obtained their data and/or the names of the authors, and it was not possible to know the quality of the information published there. Conclusion: It is possible to notice the positive effect that the Pink October campaign has, which can contribute to a greater awareness of the importance of breast selfexamination and mammography. In addition, it is necessary to be careful when looking for information in the online environment, since not all sites inform the source and/or the name of the author of the article.

KEYWORDS: breast neoplasms; information; mass screening; internet use.

\section{INTRODUCTION}

It is known that access to information in the medical field has grown a lot in recent years. Currently, it is possible to know a lot about a certain disease just by going to websites and doing a quick search on what you are trying to answer. Thus, patients have access to vast information about their pathologies and are well informed about their comorbidities. However, where do they look for information?

In his doctoral thesis, Leite Netto conducted a study with 607 women recently diagnosed with breast cancer aged 35 to 74 years old and showed that most of them ( $83 \%$ ) used the internet as their main means of communication. When asked where they learned about cancer, $45 \%$ said it was on websites and blogs, followed by television and magazines. Although they reported not trusting social media, $66 \%$ of the interviewees were users of Facebook, 35\% of Instagram, and 15\% of Youtube ${ }^{1}$.
Google provides a feature called "Google Trends", a free tool that allows you to observe the rise of searches for an established keyword or topic over time.

Therefore, this article aimed to know the prevalence of searches on Google about breast cancer and to know which keywords are most used when the population searches for this type of information. In addition, it sought to find out if the volume of these searches is influenced by the breast cancer awareness campaign, Pink October.

\section{METHODS}

This was an analytical cross-sectional study, with data collected in September and October 2020, which aimed to analyze and describe which keywords are most used by the population when doing research on the internet related to breast cancer. The recruited population extended to all those who searched for breast cancer

${ }^{1}$ Centro Universitário Fundação Assis Gurgacz - Cascavel (PR), Brazil.

${ }^{2}$ Centro de Oncologia do Oeste do Paraná - Cascavel (PR), Brazil.

*Corresponding author: drdouglasgomes@gmail.com

Conflict of interests: nothing to declare.

Received on: 05/31/2021. Accepted on: 06/28/2021. 
and related information on Google, so there is no specific number of people nor a well-defined population characteristic.

In Google Trends, when searching for a keyword, a graphic is provided in which the horizontal axis reflects time and the vertical reflects the volume of searches. Data searched by a few people, searches for the same term that are performed by the same person in a short period of time, and special characters are excluded. The numbers found reflect the trend of search interest for the keyword in a certain region and time frame, where 100 represents the peak of popularity in the search for the word, 50 means that the word has half of the popularity, and similarly, a score of 0 means that the word has less than $1 \%$ popularity in searches when compared to the peak. The numbers obtained reflect the percentage of total searches, based on the maximum rating rather than on the total number of hits.

When searching for "breast cancer" (cancer de mama) in the field "related searches" and with the filter "main", it was seen that "breast cancer" (cancer de mama), "breast cancer symptoms" (cancer de mama sintomas), "symptoms of breast cancer" (sintomas de cancer de mama), "what is breast cancer" (o que é cancer de mama), and "types of breast cancer" (tipos de cancer de mama) are the five most prevalent keywords.

An analysis of the search volume of the keywords "breast cancer" (cancer de mama), "breast self-exam" (autoexame de mama), and "mammography" (mamografia) from 2009 to 2019 was also carried out to find out what the variation of this volume over these 10 years and what their relationship with Pink October is. To narrow down the data found, the filters "Brazil" (Brasil), "Web search" (pesquisa na Web), and the years approached were used.

In addition, a search was carried out in the Google search field with these words to identify which sites feature on the first page and to know whether the articles published there have the description of the author, theoretical framework and/or technical responsible, as well as the body responsible for the website. The facts that being published on the first page of Google searches guarantees $34 \%$ more clicks to a website compared to the second page, which receives $19 \%$ of clicks ${ }^{2}$, and that, according to
Google, $75 \%$ of users who do searches do not surpass the first page of results ${ }^{3}$ were taken into account. The objective was to know whether the material being consumed by readers has a medical basis or not, since, in the online environment, information is spread quickly and easily. In order to avoid contamination in searches for data influenced by the registration of the Google account, the search was carried out in an anonymous mode.

\section{RESULTS}

Regarding the search for "breast cancer" (cancer de mama), starting in 2010, it was observed that the highest volume and peak of research occurred in the month of October. In addition, as of 2013, there was a progressive increase in the volume of searches during the months prior to October and a drop thereafter. Another point observed is the growing trend that the number of surveys had over the years (Figure 1).

Regarding the search for "breast self-examination" (autoexame de mama), it was not possible to observe a trend between 2009 and 2012; however, in relation to the months of the year, it was possible to note that there was an increase in the volume of research starting in 2010. From 2014 onward, it was noted that the trend to peak and the highest volume of research occurred in the month of October and that, in terms of volume, it remained low in the other months of the years and suffered a sudden increase when October arrived, immediately following an abrupt drop.

Regarding the researches by "mammography" (mamografia), it was found a constancy in the research line during the analyzed years, with a peak in volume from 2013, also in the month of October. And, starting in 2013, the same trend found in the keywords "breast cancer" (cancer de mama) and "breast self-examination" (autoexame de mama) was also seen, which suffered an abrupt increase in the volume of searches before the month of October, with a drop after that month (Figure 2).

With regard to the sites, 26 different articles were analyzed, nine for "breast cancer" (cancer de mama), nine for "breast self-exam" (autoexame demama), and eight for "mammography" (mamografia),

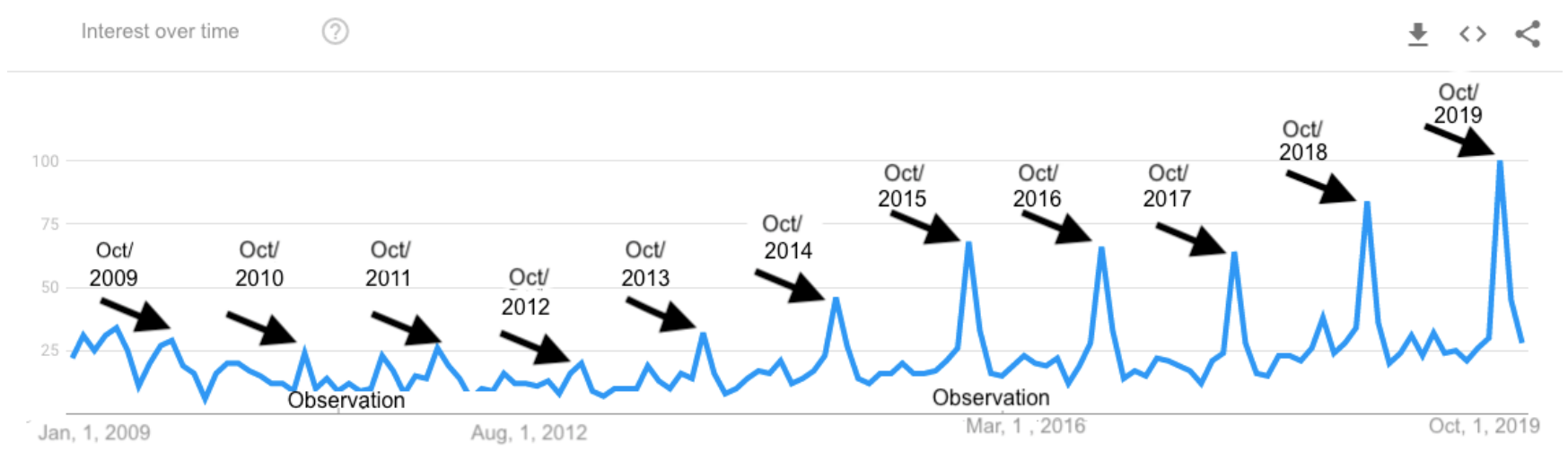

Figure 1. Evolution of research on "breast cancer" from 2009 to 2019. 
which were found on the first page of Google. It was seen that 13 of them did not specify the author's name, 13 also did not contain the information of who was the technical responsible for the publications, and nine did not contain the references of the information disclosed.

It was also notorious that the sites with the greatest chance of getting hits due to being in higher rankings in the research are in the health area, but they are not from medical professionals, medical institutions or hospitals, nor even linked with the Ministry of Health (Tables 1, 2 and 3).

It is observed that the website of the Brazilian Society of Mastology appears in seventh place when searching for "breast self-examination" (autoexame de mama) and does not appear on the first search page for the words "breast cancer" (cancer de mama) and "mammography" (mamografia).

\section{DISCUSSION}

This study managed to present the seasonality on issues related to breast cancer, as well as the impact of the Pink October campaign on search engines.
Breast cancer is the type of cancer with the highest incidence in women in the world, accounting for $24.2 \%$ of all cases in 2018. It is considered the fifth cause of death from cancer, in addition to being the most common cause of death from cancer in females ${ }^{4}$. According to the José Alencar Gomes da Silva National Cancer Institute (Instituto Nacional de Câncer José Alencar Gomes da Silva - INCA) ${ }^{5}$, it is estimated that, in the years 2020 to 2022, 66,280 new cases of breast cancer emerged in Brazil, making this the most prevalent type of cancer among women, with $29.7 \%$ of new cases per year ${ }^{5}$.

Among the ways to obtain an early diagnosis, mammography is still the most effective instrument, although the number of women who undergo this examination is still small. Socioeconomic class, level of education, and household income are among the factors that influence the performance of this exam ${ }^{6}$, and perhaps the low number of searches about breast cancer is a consequence of this lack of information.

Swedish cities that provide breast cancer screening report a $44 \%$ decrease in predicted mortality from the disease among women who are screened. In the United States, from 1980 onward, the numbers point to a decrease of $39 \%$. In addition to contributing to a reduction in mortality, screening can contribute to adherence

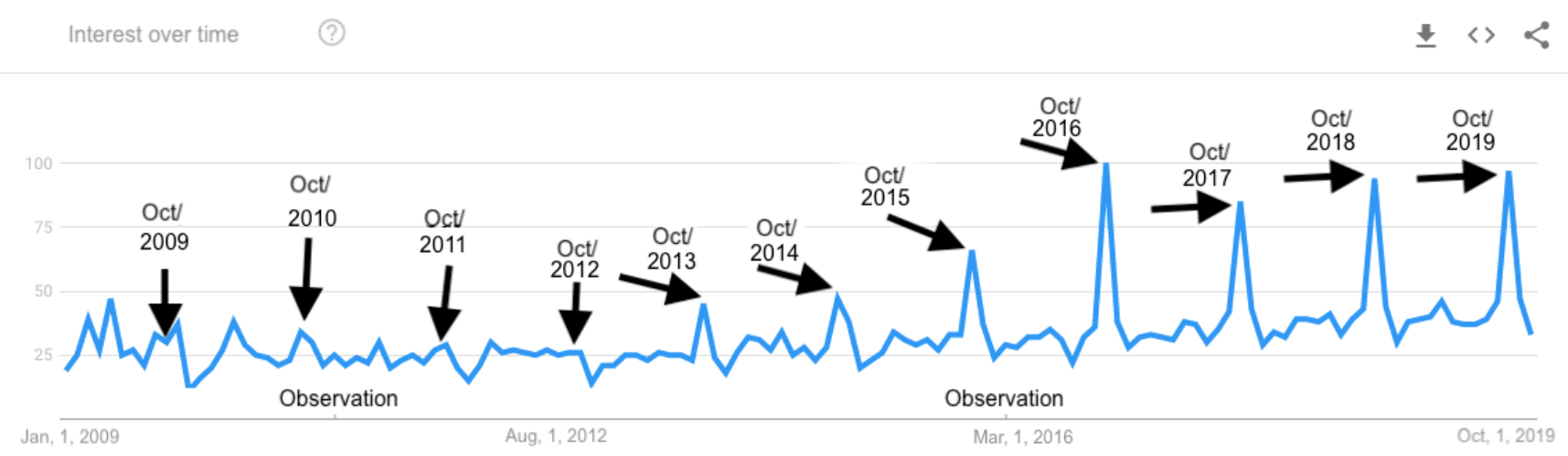

Figure 2. Survey on "mammography" (mamografia) in most months, peaking in October and decreasing after that.

Table 1. Search results for "breast cancer" (câncer de mama).

\begin{tabular}{|c|c|c|c|c|c|}
\hline & Websites & Author & $\begin{array}{l}\text { Technical } \\
\text { manager }\end{array}$ & $\begin{array}{l}\text { Textual } \\
\text { references }\end{array}$ & Type of website \\
\hline $1^{\text {st }}$ place & https://www.inca.gov.br/ & Not specified & Not specified & Without & Governmental \\
\hline $2^{\text {nd }}$ place & https://www.minhavida.com.br & "Editorial writing" & Yes, oncologist & With & Health \\
\hline $3^{\text {rd }}$ place & https://mulherconsciente.com.br & Not specified & Not specified & With & Health \\
\hline $4^{\text {th }}$ place & https://www.tuasaude.com/ & $\begin{array}{c}\text { Gynecologist and } \\
\text { Obstetrician }\end{array}$ & $\begin{array}{l}\text { Yes, gynecologist } \\
\text { and obstetrician }\end{array}$ & With & Health \\
\hline $5^{\text {th }}$ place & http://www.oncoguia.org.br/ & "Equipe Oncoguia" & Yes & With & NGO \\
\hline $6^{\text {th }}$ place & https://www.pfizer.com.br/ & Not specified & Not specified & With & $\begin{array}{c}\text { Vaccines and } \\
\text { Medicines Company }\end{array}$ \\
\hline $7^{\text {th }}$ place & https://www.gineco.com.br/ & Not specified & Yes & With & Health \\
\hline $8^{\text {th }}$ place & https://www.einstein.br/ & Not specified & Not specified & Without & Hospital \\
\hline $9^{\text {th }}$ place & https://saude.abril.com.br/ & Yes, columnist & Not specified & With & Miscellaneous \\
\hline
\end{tabular}

NGO: non-governmental organization. 
to less radical treatments and reduce treatment costs, as a consequence of the diagnosis of lesions in less advanced stages?

In the internet age, social networks are the most important places for sharing interests, information, and personal experiences, overcoming daily space and time limitations. People with health problems use social media to increase their knowledge about their disease and its respective treatments, often considering online findings as their main means of information and disrupting the doctor-patient relationship ${ }^{8}$. When analyzing the relationship with breast cancer, online research on breast self-examination has the ability to provide incorrect and/or incomplete information, which can induce the reader to take wrong measures, resulting in damage to health or delaying the disease diagnosis ${ }^{9,10}$.

Many contemporary scholars have called the present moment the "fake news era", in which erroneous information, whether generated intentionally or not, spreads quickly and may have the intention of causing harm. In the health area, they have been very common. To verify this, 131 articles were analyzed, which confirmed that the number of studies investigating health and misinformation grew over the years. Evidence was found that misinformation is abundant on the internet and more popular than correct information, consequently leading to fear, anxiety, and distrust in institutions that generate truthful content and in the population that consumes this type of information. In addition, most bad information is created by individuals with no institutional or official affiliation, which leads to questioning what readers understand as a reliable source of information ${ }^{11}$.

In an analysis of 68 sites that had information about breast selfexamination, it was found that 55 were commercial sites, of which 11 had adequate and complete content, 16 had partial content,

Table 2. Search results for "breast self-examination" (autoexame de mama).

\begin{tabular}{|c|c|c|c|c|c|}
\hline & Si Websites & Author & $\begin{array}{l}\text { Technical } \\
\text { manager }\end{array}$ & $\begin{array}{l}\text { Textual } \\
\text { references }\end{array}$ & Type of website \\
\hline $1^{\text {st }}$ place & https://medprev.online/ & Not specified & Not specified & With & Convênio \\
\hline $2^{\text {nd }}$ place & https://www.gineco.com.br/ & Not specified & Yes & With & Health \\
\hline $3^{\text {rd }}$ place & https://pebmed.com.br/ & $\begin{array}{l}\text { Gynecologist and } \\
\text { Obstetrician }\end{array}$ & Yes & With & Health \\
\hline $4^{\text {th }}$ place & https://drogariasantoremedio.com.br/ & "Admin" & Not specified & Without & Drugstore chain \\
\hline $5^{\text {th }}$ place & https://www.inca.gov.br/ & Not specified & Not specified & With & Governmental \\
\hline $6^{\text {th }}$ place & https://www.tuasaude.com/ & $\begin{array}{l}\text { Gynecologist and } \\
\text { Obstetrician }\end{array}$ & $\begin{array}{l}\text { Gynecologist and } \\
\text { Obstetrician }\end{array}$ & Without & Health \\
\hline $7^{\text {th }}$ place & https://www.sbmastologia.com.br/ & Not specified & Yes & With & Health \\
\hline $8^{\text {th }}$ place & https://www.youtube.com/ & $\begin{array}{l}\text { Nutritionist } \\
\text { Channel }\end{array}$ & Not specified & Without & Miscellaneous \\
\hline $9^{\text {th }}$ place & https://laboratoriosobrinho.com.br/ & Not specified & Not specified & With & Clinical Laboratory \\
\hline
\end{tabular}

Table 3. Search results for "mammography" (mamografia).

\begin{tabular}{|c|c|c|c|c|c|}
\hline & Websites & Author & $\begin{array}{l}\text { Technical } \\
\text { manager }\end{array}$ & $\begin{array}{l}\text { Textual } \\
\text { references }\end{array}$ & Type of website \\
\hline $1^{\text {st }}$ place & https://altadiagnosticos.com.br/ & Not specified & Not specified & Without & Laboratory \\
\hline $2^{\text {nd }}$ place & https://saude.abril.com.br/ & Yes, columnist & Not specified & With & Miscellaneous \\
\hline $3^{\text {rd }}$ place & https://www.americasamigas.org.br/ & Not specified & Yes & With & $\begin{array}{c}\text { Civil Society } \\
\text { Organization } \\
\text { (Organização da } \\
\text { Sociedade Civil - OSCIP) } \\
\text { and Human Rights } \\
\text { Promoting Entity }\end{array}$ \\
\hline $4^{\text {th }}$ place & https://www.minhavida.com.br/ & With & Yes & With & Health \\
\hline $5^{\text {th }}$ place & http://www.oncoguia.org.br/ & $\begin{array}{l}\text { "Oncoguide } \\
\text { team" (Equipe } \\
\text { Oncoguia) }\end{array}$ & Yes & Without & NGO \\
\hline $6^{\text {th }}$ place & https://drauziovarella.uol.com.br/ & With & Yes & Without & Doctor \\
\hline $7^{\text {th }}$ place & https://laboratorioexame.com.br/ & Not specified & Not specified & With & Laboratory \\
\hline $8^{\text {th }}$ place & https://www.msdmanuals.com/ & With & Yes & Without & Health \\
\hline
\end{tabular}

NGO: non-governmental organization. 
and 23 had inadequate and/or incomplete content. With regard to guidelines, one website said that self-examination has the ability to prevent breast cancer and nine said that it allows for an early diagnosis or that it is the best resource for initial diagnosis. Only four listed possible unfavorable effects related to self-examination as a methodology associated with early diagnosis ${ }^{10}$.

In our study, the results obtained showed that even sites with high-quality content, such as INCA and others related to the health area, do not present the reference source or the authors who wrote the text, a fact that does not disqualify the material available to the public, which would, however, be further qualified if these sources were cited.

One study sought to evaluate Youtube with the keyword "breast self-examination” (autoexame de mama). Initially, 200 videos were selected, of which 33 were classified as useful by two physicians and 54 were classified as misleading. The videos that contained useful information had good reliability, quality, and content and, when compared to the others, were longer. Videos with questionable content were mostly posted by individuals and their views per day were higher than those with correct information, and the total number of views was also higher in the group of videos with erroneous information ${ }^{12}$.

As for the existing fatalism in relation to cancer and the amount of information found about it in the virtual environment, different consequences may occur among patients who have different levels of education. In those with a lower level of education and greater exposure to information via medical and health websites, this exposure ended up increasing their suffering in relation to cancer, contrary to what occurred with patients with a higher level of education, for whom this exposure reduced their suffering. This difference can be explained by the fact that patients with a higher level of education had greater literary skills to filter the information they were faced with, as opposed to patients with a lower level of education ${ }^{13}$.

In the study by Leite Netto ${ }^{1}$, the women who participated in the research were treated in the city of São Paulo, which is a metropolitan city and state capital, a place where women frequently use digital media. This fact denotes a certain selection bias in the results presented.

The history of Pink October begins in the 20th century, when the famous pink bow, which became a symbol of this campaign, was launched. The movement began in the United States, when several states that had isolated actions in relation to breast cancer and mammography joined together and made the month of October the official month for the prevention of breast cancer. This movement achieved worldwide popularity and, in 2002, the first action related to Pink October took place in Brazil: the lighting of the monument Obelisco do Ibirapuera.

Our study was able to demonstrate the importance of the Pink October awareness campaign in Brazil, from 2009 to 2019. Through the graphics displayed, it is possible to analyze the trend of the occurrence of search peaks for words related to breast cancer in October, in addition to a growing line with regard to the volume of research on these words over the years, demonstrating that more and more research has been done on this type of cancer. Thus, it is possible to note the growing interest of the population in the early diagnosis of a public health problem and the importance of campaigns that will publicize the importance of screening and enhance the performance of mammography.

Like our study, research from Malaysia assessed interest in breast cancer screening from 2007 to 2018 using Google Trends. A significant increase in research was also seen during the month of October, which shows increased interest in monitoring and early diagnosis of breast cancer not only in Brazil, as well as demonstrates that this interest is also correlated with the Pink October campaign ${ }^{14}$.

Another Brazilian work was carried out with the aim of evaluating the impact of cancer-related campaigns on the Brazilian population, not only using data obtained from Google Trends, but also analyzing prostate cancer. Their results showed that, although breast cancer is not the most prevalent type of cancer in Brazil, it is the one of greatest interest to the Brazilian population, with three times the number of researches in relation to prostate cancer ${ }^{15}$.

This internet cancer research behavior is likely to be related to the Pink October and Blue November campaigns. This shows that such campaigns have the strong effect of influencing the population's interest in the topics and in carrying out screening tests, such as mammography, which is reflected in the increase in the search volume in the months in question, verified through the Google Trends tool ${ }^{15}$.

The increased search for information leads to greater awareness among the population about certain types of diseases, as well as on how to prevent and treat them, but it also affects the public health system, with groups that are not at risk overloading the system. Pink October was a success for increasing the search for information and mobilizing knowledge about breast cancer ${ }^{15}$.

This relationship between Pink October and mammography can be seen in a survey conducted from 2014 to $2016^{16}$, which showed that, in these years, there was a significant increase in the total number of mammograms performed during the month of October when compared to other months of the year. This can be considered an indirect marker of the positive influence that the campaign exerts on society, in addition to being a reflection of the population's increased search for information about breast cancer.

The present study sought to assess in general terms the access to information about breast cancer, however, using Google Trends, it was not possible to quantify the number of accesses or the gender and age of those who performed such searches. This fact ends up limiting the assessment of the impact of this on breast cancer awareness and on the performance of self-examination and mammography, especially in the population for which these tools are recommended for screening for the pathology. Likewise, the quality of the information presented on the websites was not evaluated in terms of the form and updating of the information presented, but only regarding the description of theoretical references, authorship, technical responsible or possible body responsible for the website. 
Our study was able to show the carelessness that many sites show in not specifying the authorship and reference of the material presented, making it necessary to improve the legislation on this subject. Presenting the authorship and bibliographic references only qualifies the content presented and is a procedure that should be used systematically in health-related websites. It is expected that new studies emerge to contribute to the theme, which can quantify and assess the number of searches on the internet about breast cancer, as well as the gender and age of those who carry out such searches.

\section{CONCLUSION}

Through our study, it was possible to demonstrate the importance of health campaigns in terms of population awareness. Pink October is a reflection of this, since most of the search peaks of the analyzed keywords and which were related to breast cancer occurred in the month of October. Thus, one can see the positive effect of this campaign to raise awareness among the population about breast cancer and its screening methodologies, such as self-examination and mammography, as people start looking for ways to get informed about the disease.

\section{AUTHORS' CONTRIBUTION}

D.S.: supervision, conceptualization, methodology, writing review \& editing.

N.O.: conceptualization, data curation, formal analysis, investigation, methodology, project administration, resources, software, validation, visualization, writing - original draft, writing review e editing.

\section{REFERENCES}

1. Leite Netto J. Influência da mídia no diagnóstico de câncer de mama [tese]. São Paulo: Fundação Antônio Prudente; 2019.

2. Rocha L. Como estar na primeira página de pesquisa do Google [Internet]. Brasil: Elevon; 2018 [cited on Mar 28, 2021]. Available from: https://www.elevon.com.br/primeira-pagina-do-google/

3. Sobreira F. Primeira página do Google NÃO é o mais importante [Internet]. Brasil: Flamm; 2018 [cited on Mar 28, 2021]. Available from: https://flammo.com.br/blog/primeirapagina-do-google/

4. World Health Organization. Cancer Today [Internet]. World Health Organization; 2018 [cited on Mar 17, 2020]. Available from: https://gco.iarc.fr/today/home

5. INCA. Estimativa 2020: incidencia de cancer no Brasil [Internet]. Síntese de resultados e comentários: Estimativa 2020 [Internet]. INCA; 2020 [cited on Mar 27, 2020]. Available from: https://www.inca.gov.br/estimativa/sintese-deresultados-e-comentarios

6. Veras R.Fórum.Envelhecimento populacionale as informações de saúde do PNAD: Demandas e desafios contemporâneos. Introdução. Cad Saúde Pública. 2007;23(10):2463-6. https:// doi.org/10.1590/S0102-311X2007001000020

7. Godinho ER, Koch HA. Fontes utilizadas pelas mulheres para aquisição de conhecimentos sobre câncer de mama. Radiol Bras. 2005;38(3):169-73. https://doi.org/10.1590/S010039842005000300004

8. Lavorgna L, De Stefano M, Sparaco M, Moccia M, Abbadessa G, Montella P, et al. Fake news, influencers and healthrelated professional participation on the Web: A pilot study on a social-network of people with Multiple Sclerosis. Mult Scler Relat Disord. 2018;25:175-8. https://doi.org/10.1016/j. msard.2018.07.046
9. Kunst H, Groot D, Latthe PM, Latthe M, Khan KS. Accuracy of information on apparently credible websites: survey of five common health topics Follow up of quality of public oriented health information on the world wideweb:systematicre-evaluation.BrMed J. 2002;324(7337):581-2.https://doi.org/10.1136/bmj.324.7337.581

10. Cubas MR, Felchner PCZ. Análise das fontes de informação sobre os autoexames da mama disponíveis nainternet. Ciênc Saúde Coletiva. 2012;17(4):965-70.https://doi.org/10.1590/S1413-81232012000400018

11. Wang Y, McKee M, Torbica A, Stuckler D. Systematic Literature Review on the Spread of Health-related Misinformation on Social Media. Soc Sci Med. 2019;240:112552. https://doi. org/10.1016/j.socscimed.2019.112552

12. Esen E, Aslan M, Sonbahar BÇ, Kerimoğlu RS. YouTube English videos as a source of information on breast self-examination. Breast Cancer Res Treat. 2019;173(3):629-35. https://doi. org/10.1007/s10549-018-5044-z

13. ChungJE,Lee C-J. The impact of cancer information online on cancer fatalism: education and eHealth literacy as moderators. Health Educ Res. 2019;34(6):543-55. https://doi.org/10.1093/her/cyz027

14. Mohamad M, Kok HS. Using Google trends data to study public interest in breast cancer screening in Malaysia. Asian Pacific J Cancer Prev. 2019;20(5):1427-32. https://dx.doi.org/10. 31557\%2FAPJCP.2019.20.5.1427

15. Quintanilha LF, Souza LN, Sanches D, Demarco RS, Fukutani KF. The impact of cancer campaigns in Brazil: A Google Trends analysis. Ecancermedicalscience. 2019;13:963. https://dx.doi. org/10.3332\%2Fecancer.2019.963

16. Vazzoller PR, Fernandes YCF, Gotardo BA, Ruhnke J, Soltau DG. Impact of the pink October in the mammographic screening adherence in a reference center in oncology. Mastology. 2017;27(3):194-8.https://dx.doi.org/10.5327/Z2594539420170000212 